\title{
Groundwater resources in the State of São Paulo (Brazil): the application of indicators
}

\author{
RICARDO HIRATA ${ }^{1}$, ALEXANDRA SUHOGUSOFF ${ }^{1}$ and AMÉLIA FERNANDES ${ }^{2}$ \\ ${ }^{1}$ Instituto de Geociências, Universidade de São Paulo, Rua do Lago, 562, Butantã, 05508-080 São Paulo, SP, Brasil \\ ${ }^{2}$ Instituto Geológico, Secretaria do Meio Ambiente do Estado de São Paulo \\ Avenida Miguel Stéfano, 3900, Água Funda, 04301-903 São Paulo, SP, Brasil \\ Manuscript received on March 3, 2005; accepted for publication on April 17, 2006; \\ presented by ALCIDES N. SIAL
}

\begin{abstract}
Indicators, for groundwater resources, have mostly been employed to define the present status and the degradation tendency, regarding both quantity (under- or overexploitation) and quality (natural and anthropic contamination). This work presents the application of indicators in order to draw a picture of the groundwater resources situation in the 22 Water Resource Management Units (WRMU) of the State of São Paulo. The seven Indicators (I1 to I7) applied provide a general overview of groundwater dependence (I1, I2), availability (I3, I4), and quality (I5, I6, I7). Considering public supply (Indicator 1), one observes that 9 WRMUs show high ( $>50 \%$ of the population supplied by groundwater), 6 , intermediate $(49-25 \%)$, and 7, low $(<24 \%)$ dependence on groundwater. Indicators 3 and 4 show that the resource still presents a great potential for further abstractions in most of the WRMUs, although there is evidence of overexploitation in the Upper Tietê, Turvo/Grande, and Pardo basins, and low availability in the Upper Tietê, Piracicaba/Capivari/Jundiai, and Turvo/Grande. Indicator 5 (aquifer natural vulnerability) denotes that the WRMUs 2, 4, 8, 13, 14 and 18-22 (part of the recharge area of Guarani Aquifer System) need more attention mainly where large contaminant loads are present. Indicator 6 shows the general excellent natural quality of groundwater, although it also denotes that 3 WRMUs need special consideration due to chromium and fluoride contamination. Indicator 7 demonstrates a close relationship between groundwater contamination occurrence and density/type of land occupation.
\end{abstract}

Key words: groundwater, São Paulo, public water supply, management, indicators.

\section{INTRODUCTION}

With a population of 37 million inhabitants $(93 \%$ in urban areas), a territory of $248209 \mathrm{~km}^{2}$, and the concentration of $36 \%$ of the country GDP, São Paulo is the most populous and economically important State of Brazil. Its dependence on groundwater is demonstrated by the fact that of its 645 municipalities, $70 \%$ are totally or partially supplied by this resource.

Although groundwater resources perform such an important role, little has been done in order to protect them. Limited knowledge about recharge of the aquifers,

Correspondence to: Ricardo Hirata

E-mail: rhirata@usp.br stored volumes, and actual exploitation precludes the elaboration of consistent policies for the sustainable management of this resource. Likewise, the number of known cases of anthropic contamination is still small when compared to the territorial occupation history. The good natural quality of the groundwater and its abundance have warranted that the overexploitation has been restricted to some localities, although evidence of its rapid evolution exists.

This work presents the application of indicators that are numeric or non-numeric qualifiers. They result from mathematic operations, involving quantitative information originated from specific areas and time periods, and 
aim at (1) describing the situation, and (2) identifying the potentiality and constraints related to quality (natural and anthropic contamination) and quantity of the aquifers in those areas. They can be used as important tools of communication with the policy-makers and the public in general and, when associated with time-series and reliable aquifer conceptual models, may be used to forecast likely future scenarios. The application of these indicators was useful for drawing a picture of the groundwater resources situation in its 22 Water Resources Management Units (WRMUs). WRMUs are operational units with a tripartite (State government, municipal governments and civil society) administration (water authorities), and correspond geographically to the main hydrographic basins of the State of São Paulo.

\section{CHARACTERIZATION OF THE AQUIFER SYSTEMS OF THE STATE OF SÃO PAULO}

The State of São Paulo is constituted of two hydrogeologic provinces where the aquifer systems are inserted, namely: (1) the Paraná Volcano-Sedimentary Basin, which encompasses Bauru, Serra Geral, Guarani and Tubarão aquifer systems; and (2) the Eastern Massif of the Southeast, which encompasses the Precambrian, Taubaté, São Paulo and Shoreline aquifers. A short description of these aquifers can be found on Table I, and their occurrence in the State in Figure 1.

\section{ReCharge AND AQUifer Potentiality}

Renewable groundwater resource corresponds to the "exploitable groundwater reserve", as used elsewhere, and is herein defined as the difference between the recharge and the discharge that maintains the minimum baseflow in the rivers. In other words, it consists of the maximum discharge that can be withdrawn in a watershed so as to not cause negative impacts on the subsurface and surface water bodies. The estimates of the reserves, for each WRMU, can be found in the Situation Reports of the water resources of State of São Paulo (digital technical report, unpublished data) and are depicted in Table II. When considering these values, it is important to consider some limitations such as: the methodology of calculation was not the same for all 22 WRMUs, precluding a direct comparison among them; the recharge calculation did not take into account the urbanization ef- fects, such as the impermeabilization and the losses of the supply and sanitation systems (excepting the case of the WRMU 6, namely, Upper Tietê Basin). The latter is significant in some units, for instance, in the Upper Tietê Basin it is estimated that the no natural recharge reaches up to $13 \mathrm{~m}^{3} / \mathrm{s}$, being this $31 \%$ larger than the exploitation that has been practiced in the basin.

When one considers the current knowledge of the aquifer systems, some inconsistencies, regarding the calculated exploitable resources (Table II), become evident. For instance, the excellent yielding achieved in Guarani Aquifer is not compatible with the calculated resources that are a consequence of the underestimate of its recharge. The calculations should consider that the recharge has probably been raised by the systematic and extensive pumping, at least in some municipalities (Sracek and Hirata 2002). On the other hand, the largest estimated resources of WRMU 11 (Ribeira de Iguape/South Shoreline) seem to be disagreeable with an aquifer system that consists mainly of crystalline PreCambrian rocks (gneisses, granites and metasedimentary rocks), which do not allow a large rate of infiltration.

\section{GROUNDWATER EXPLOITATION}

The groundwater resources play a major role for the public water supply in the State of São Paulo. In about $50 \%$ of the municipalities, the majority concentrated in the Northwestern portion of the State, the groundwater constitutes 75 to $100 \%$ of their water supply (Figure 2). The evaluation of the total exploited discharges for each municipality, which were compiled from SEADE Foundation database (http://www.seade.gov.br/, access on $15 / 10 / 04$ ), demonstrates that the public supply system has exploited up to $18.3 \mathrm{~m}^{3} / \mathrm{s}$. In the North, Central and Western portions of the State, the abstraction comes mainly from the Bauru Aquifer System (mainly Adamantina and Caiuá aquifers) and, for the largest cities, from the Guarani Aquifer System, where the well depths may be greater than $500 \mathrm{~m}$ (Table III).

Some known facts, with regard to private exploitation, are: the totality of the industries installed in the Metropolitan Region of Campinas (in the WRMU 5) own wells; the total abstraction in the Upper Tietê Basin (WRMU 6), withdrawn by the estimated 7000 private wells, reaches $8 \mathrm{~m}^{3} / \mathrm{s}$ (for the year of 2000); even in the 


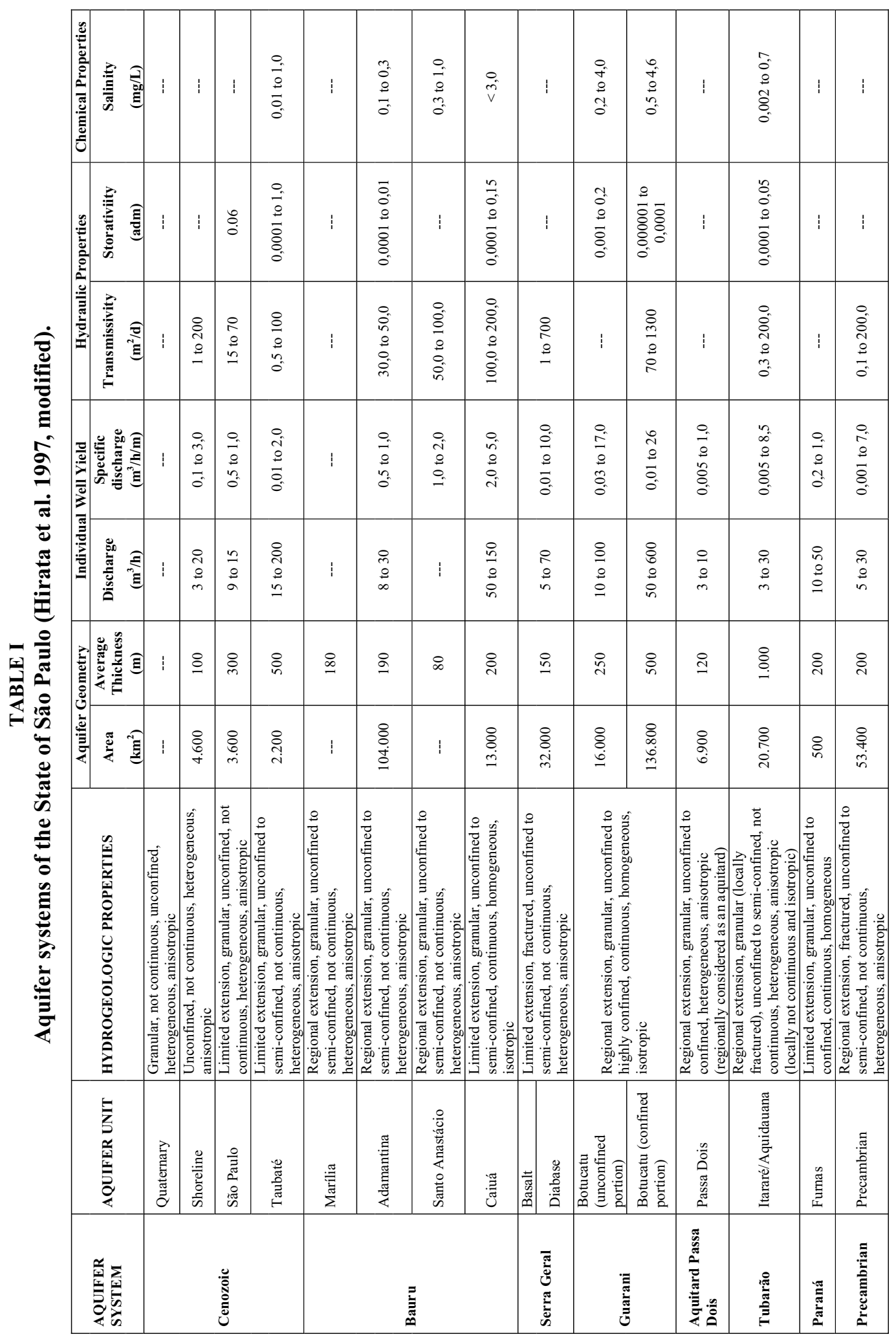




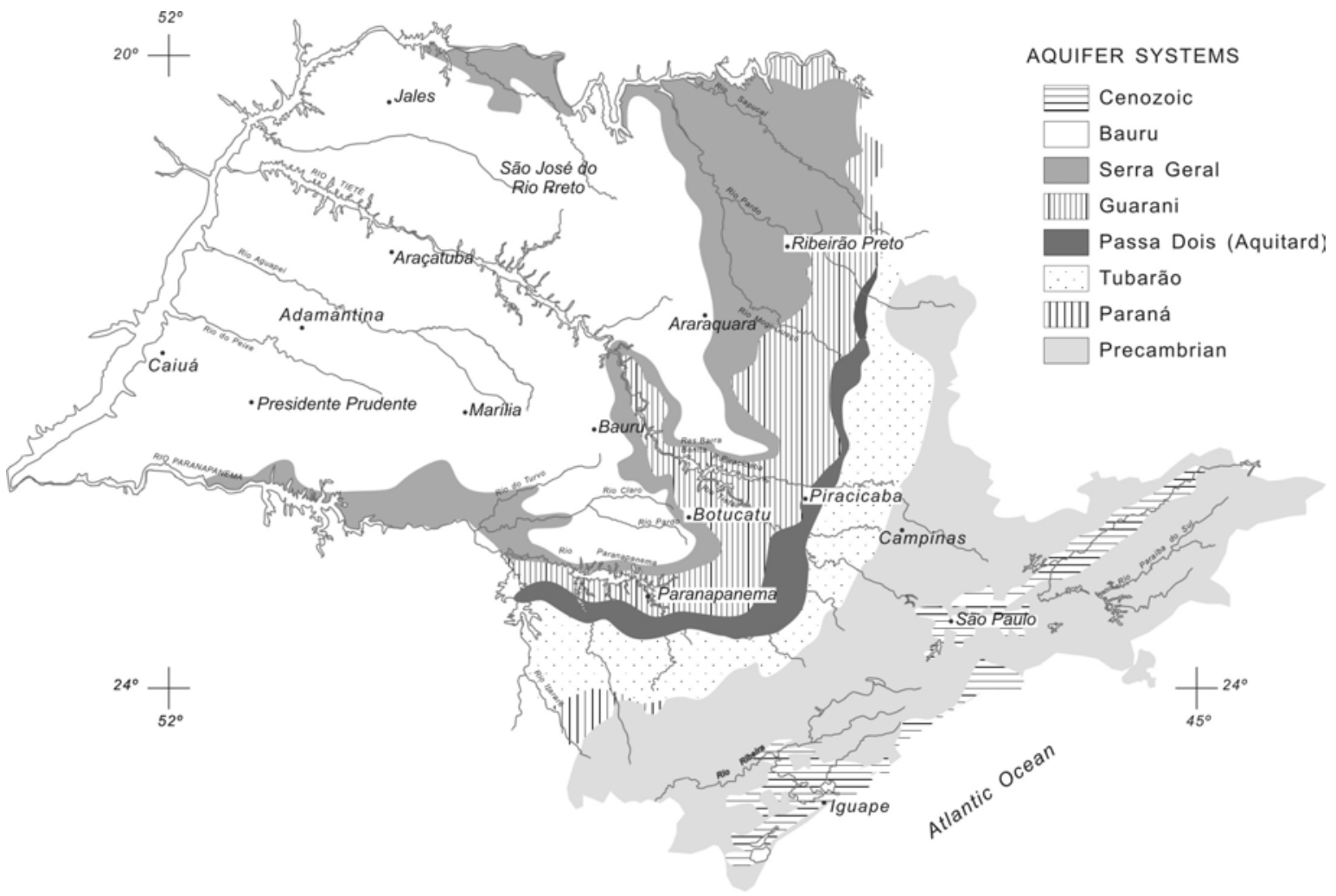

Fig. 1 - Main aquifer systems in the state of São Paulo.

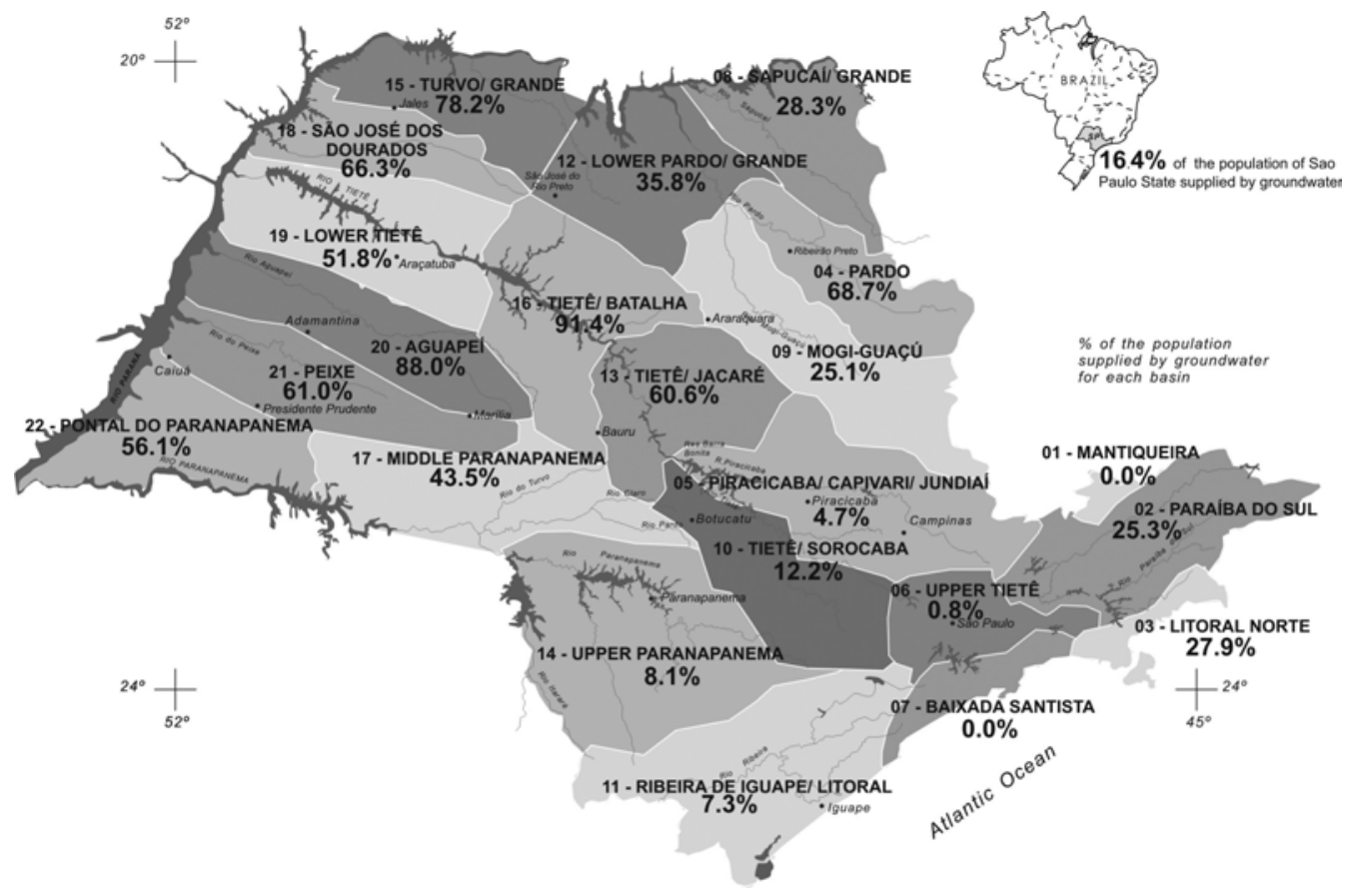

Fig. 2 - Percentage of the population supplied by groundwater for each Water Resource Management Units (WRMU) (associated to the main watershed) in the state of São Paulo. 
TABLE II

Area, precipitation, renewable groundwater resources for each Water Resource Management Units (WRMU) of the State of São Paulo.

\begin{tabular}{|c|c|c|c|}
\hline HRMU & $\begin{array}{c}\text { Area } \\
\left(\mathrm{km}^{2}\right)\end{array}$ & $\begin{array}{c}\text { Precipitation } \\
\text { average }\left(\mathrm{m}^{3} / \mathrm{s}\right)\end{array}$ & $\begin{array}{c}\text { Renewable } \\
\text { groundwater } \\
\text { resources }\left(\mathrm{m}^{3} / \mathrm{s}\right)\end{array}$ \\
\hline 01 - Mantiqueira & 675 & 41.74 & 2 \\
\hline 02 - Paraiba do Sul & 14444 & 645.80 & 20 \\
\hline 03 - Litoral Norte & 1948 & 165.55 & 8 \\
\hline 04 - Pardo & 8993 & 427.75 & 10 \\
\hline 05 - Piracicaba/Capivari/Jundiaí & 14178 & 621.32 & 24 \\
\hline 06 - Upper Tietê & 5868 & 269.62 & 19 \\
\hline 07 - Baixada Santista & 2818 & 238.59 & 15 \\
\hline 08 - Sapucaí/Grande & 9125 & 439.81 & 11 \\
\hline 09 - Mogi-Guaçu & 15004 & 675.60 & 17 \\
\hline 10 - Middle Tietê/Sorocaba & 11829 & 476.37 & 8 \\
\hline 11 - Ribeira de Iguape/Litoral Sul & 17068 & 980.15 & 58 \\
\hline 12 - Lower Pardo/Grande & 7239 & 315.40 & 11 \\
\hline 13 - Tietê/Jacaré & 11779 & 489.30 & 13 \\
\hline 14 - Upper Paranapanema & 22689 & 928.83 & 25 \\
\hline 15 - Turvo/Grande & 15925 & 631.22 & 11 \\
\hline 16 - Tietê/Batalha & 13149 & 513.68 & 10 \\
\hline 17 - Middle Paranapanema & 16749 & 690.44 & 21 \\
\hline 18 - São José dos Dourados & 6783 & 268.86 & 4 \\
\hline 19 - Lower Tietê & 15588 & 598.09 & 12 \\
\hline 20 - Aguapei & 13196 & 510.50 & 11 \\
\hline $21-$ Peixe & 10769 & 426.12 & 15 \\
\hline 22 - Pontal do Paranapanema & 12395 & 479.12 & 15 \\
\hline State of São Paulo & 248111 & 10834.60 & 336 \\
\hline
\end{tabular}

WRMUs that are constituted of crystalline Pre-Cambrian rocks, an extensive abstraction for industrial supply and for autonomous household is practiced. Despite of these facts, little knowledge is available with regard to groundwater exploited volumes by private wells. Furthermore, in contrast with the surface waters, the demands, according to different types of use, are more difficult to estimate.

7779 wells are registered in the databank of the DAEE (Department of Water and Electric Energy of the State of São Paulo), however it is estimated that the State of São Paulo territory contains around 30000 currently active boreholes (G. Rocha, unpublished data), and several tens of thousands of dug wells and mini-wells (small diameter, shallow, and inexpensive). This situation clearly demonstrates the lack of control over the exploitation of groundwater by the government institutions.
Despite of this limitation, estimates of the groundwater exploited volumes, for each of the 22 WRMU, are presented in the Situation Reports of these units (Table III); the sum of these estimates results in $41.8 \mathrm{~m}^{3} / \mathrm{s}$. From this, around $18.3 \mathrm{~m}^{3} / \mathrm{s}$ (SEADE 2004) are used for public supply. In Table III, one can observe that the Upper Tietê $\left(7.9 \mathrm{~m}^{3} / \mathrm{s}\right)$, Turvo/Grande $\left(5.5 \mathrm{~m}^{3} / \mathrm{s}\right)$, Mogi-Guaçu $\left(4.8 \mathrm{~m}^{3} / \mathrm{s}\right)$, Paraíba do Sul $\left(3.6 \mathrm{~m}^{3} / \mathrm{s}\right)$, and Middle Paranapanema (probably $3.2 \mathrm{~m}^{3} / \mathrm{s}$ ) practice the greater values of total abstraction. The abstractions in the other units are smaller than $1.5 \mathrm{~m}^{3} / \mathrm{s}$.

\section{GROUNDWATER NATURAL QUALITY}

Groundwater in São Paulo State is, in general, of excellent quality, being potable and without restrictions for most uses. For the public supply, the only necessary 
TABLE III

Groundwater use for the State of São Paulo (SEADE 2004, modified).

\begin{tabular}{|c|c|c|c|c|c|}
\hline \multirow[b]{2}{*}{ HRMU } & \multicolumn{4}{|c|}{ Use $\left(\mathrm{m}^{3} / \mathrm{s}\right)$} & \multirow[b]{2}{*}{$\begin{array}{c}\text { Total } \\
\text { abstraction } \\
\left(\mathrm{m}^{3} / \mathrm{s}\right)\end{array}$} \\
\hline & $\begin{array}{c}\text { Domestic and } \\
\text { Public } \\
\text { Supply }\end{array}$ & Industrial & Rural & Other & \\
\hline 01 - Mantiqueira & - & - & - & - & 0.0 \\
\hline 02 - Paraiba do Sul & 1.7 & 1.8 & 0.8 & - & 3.6 \\
\hline 03 - Litoral Norte & 0.1 & - & - & - & 0.1 \\
\hline 04 - Pardo & 3.5 & - & - & - & 4.4 \\
\hline 05 - Piracicaba/Capivari/Jundiaí & 0.4 & 0.5 & - & - & 1.0 \\
\hline 06 - Upper Tietê & 2.8 & 3.4 & - & 1.7 & 7.9 \\
\hline 07 - Baixada Santista & 0.1 & 0.0 & - & - & 0.1 \\
\hline 08 - Sapucaí/Grande & - & - & - & - & 0.9 \\
\hline 09 - Mogi-Guaçu & 1.0 & 3.7 & 0.1 & 0.0 & 4.8 \\
\hline 10 - Tietê/Sorocaba & 0.4 & - & - & - & 0.4 \\
\hline 11 - Ribeira de Iguape/Litoral Sul & 0.5 & - & - & - & 0.5 \\
\hline 12 - Lower Pardo/Grande & 0.2 & 0.2 & - & - & 0.4 \\
\hline 13 - Tietê/Jacaré & 3.0 & 0.3 & - & 0.3 & 3.7 \\
\hline 14 - Upper Paranapanema & - & - & - & - & 0.3 \\
\hline 15 - Turvo/Grande & - & - & - & - & 5.5 \\
\hline 16 - Tietê/Batalha & 1.0 & - & - & - & 1.0 \\
\hline 17 - Middle Paranapanema & 0.1 & - & 3.1 & - & 3.2 \\
\hline 18 - São José dos Dourados & 0.5 & 0.0 & - & 0.0 & 0.5 \\
\hline 19 - Lower Tietê & 0.7 & - & - & - & 0.7 \\
\hline 20 - Aguapei & 1.1 & - & - & - & 1.1 \\
\hline 21 - Peixe & 1.2 & - & - & - & 1.2 \\
\hline 22 - Pontal do Paranapanema & - & - & - & - & 0.6 \\
\hline State of São Paulo & 18.3 & - & - & - & 41.8 \\
\hline
\end{tabular}

measures are the chlorination and, in some cases, the fluoridation.

Cases of chromium and fluoride natural contamination are known in some basins. Chromium is mostly observed in water of some deeper and heavily exploited wells of the Adamantina Aquifer in São José dos Dourados, Turvo/Grande and Lower Pardo/Grande WRMUs. It is geographically limited to the Northwestern portion of the State of São Paulo (R. Hirata and G. Rodolfi unpublished data, M.L.N. Almodovar, unpublished data, CETESB 2004). This is explained by the fact that the source of the sediments, of the Adamantina Formation in this region, was originated in the Triângulo Mineiro (MG), where minerals of chromium (e.g., chromite and some types of garnet) were available. Fluoride affects mainly the Guarani (Botucatu and Piramboia forma- tions), Serra Geral, and, locally, Tubarão (Itararé Formation) aquifer systems. The origin of the fluoride is not yet clearly understood, although it is generally accepted that it is associated with major faults (Perroni et al. 1985). It occurs in one or more areas of Pontal do Paranapanema, Tietê/Batalha, Middle Paranapanema and Lower Tietê WRMUs, although it generally affects only less than 5\% of the whole area of each unit.

\section{GROUNDWATER INDICATORS}

The indicators allow the definition of the present status or trends for a specific quality or parameter of a defined area and also the comparison of different regions (UNESCO/IAEA/IAH/UNECE 2004).

The most common use of indicators is describing the state of the resource, although regular measurements 
of them provide time series that can be used either for predicting future trends or responses to the management. They, therefore, act as an important communication tool for policy-makers and the public, in general, and also permit to evaluate the effectiveness of specific policy actions and subsidize the development of new actions. An indicator value can also be compared to a reference condition and so it can be used as a tool for assessment.

Indicators, for groundwater resources, have mostly been employed in order to define the present status, on a regional scale, and the degradation tendency, with regard to both quantity (under- or overexploitation) and quality (natural and anthropic contamination). The formulation of the indicators, herein presented, was based partially on UNESCO/IAEA/IAH/UNECE (2004) and Vrba et al. (2005). As described in the following sections, specific combinations of the seven indicators provide a general picture of the WRMU with regard to three aspects, namely, (1) dependence, (2) availability, and (3) quality of groundwater (Table IV. Figure 3) synoptically represents these three aspects using simple and intuitive "smiling faces".

As is depicted in Table V, each of the 22 WRMUs was classified in three categories of increasing attention, namely, observation, attention, and alert, according to its situation with regard to each Indicator.

\section{INDICATORS OF GROUNDWATER DEPENDENCE}

The formulae related to the indicators of groundwater dependence are illustrated in Table IV. Indicator 1 (I1) is concerned with the role of groundwater for public supply. Categories low, intermediate and high correspond to: less than $25 \%, 25$ to $50 \%$, and larger than $50 \%$, respectively. 9 WRMUs show strong dependence on groundwater (supply of more than $50 \%$ of the population); 6 , intermediate (49 to $25 \%$ ); e 7 , low $(<24 \%$ ) (Table V, Figure 2). The municipalities of the Western and Central portions of the State of São Paulo, whose population corresponds to $16.4 \%$ of the State, are strongly supported by groundwater abstraction. The most dependent basin is the Tietê/Batalha (91\%), being followed by Aguapeí (88\%), Turvo Grande (78\%), Pardo (69\%), São José dos Dourados (66\%), Peixe (61\%), Tietê/Jacaré (61\%), Pontal do Paranapanema (56\%) and Lower Tietê (52\%). All of these are in category high and the other basins, that present a degree of dependency inferior to $50 \%$, in categories intermediate and low (Table V).

Indicator 2 (I2) expresses the degree of groundwater participation in water supply for all uses, that is, the abstraction of groundwater compared to the total, ground- and surface water, one. In the State of São Paulo, the groundwater contributes with $11 \%$ of the total used water. The majority of the WRMU are in category low (I2 $<25 \%)$, three in intermediate $(25 \% \leq \mathrm{I} 2<50 \%)$, and one in high ( $\mathrm{I} 2 \geq 50 \%)$. The major contributions of groundwater, according to the Situation Reports data, are found in São José dos Dourados (50\%), Turvo/Grande (32\%), Tietê/Jacaré (29\%) and Middle Paranapanema (26\%) (Table IV).

\section{INDICATORS OF GROUNDWATER AVAILABILITY}

Indicator 3 (I3) (Table IV relates the renewable groundwater resources, defined in the section "recharge and aquifer vulnerability", to the total population. The categories low, intermediate and high, for this Indicator, correspond to larger than $1500 \mathrm{~L} /$ inhab/day, 500 to $1500 \mathrm{~L} / \mathrm{inh} a b /$ day, and less than $500 \mathrm{~L} / \mathrm{inhab} /$ day, respectively (Table V). In the State of São Paulo, an average discharge of $787 \mathrm{~L} / \mathrm{inh} a b /$ day is estimated. As one could expect, the Upper Tietê Basin (WRMU 6), with $93 \mathrm{~L} / \mathrm{inh} a b /$ day, is the most critical, followed by Piracicaba/Capivari/Jundiai (482 L/inhab/day) and Tietê/Sorocaba (433 L/inhab/ day). Significant drawdowns of the potentiometric surfaces are reported for the Upper Tietê Basin (Hirata et al. 2002, Hirata and Ferreira 2001) and also for Turvo/Grande (São José do Rio Preto municipality) and Pardo (Ribeirão Preto municipality) basins (São Paulo 2004a, b). Nevertheless, in many of the WRMUs, for instance Ribeira de Iguape (13973 L/inhab/day), Litoral Sul (3186 L/inhab/day), Upper Paranapanema (3186 L/inhab/day), Lower Pardo/ Grande (3050 L/inhab/day), and Middle Parnapanema (2891 L/inhab/day), the availability is high, mainly due to the relatively low amount of inhabitants in these regions. The present study did not take into account the potentiality of the Guarani Aquifer in its confined portion. This aquifer, as concluded by previous investigations, is the great groundwater reservoir of the State of São Paulo.

Indicator 4 (I4) expresses how much water has been abstracted with regard to the renewable groundwater re- 
TABLE IV

Description of the groundwater indicators for the State of São Paulo.

\begin{tabular}{|c|c|c|c|}
\hline $\begin{array}{l}\text { Groundwater } \\
\text { with regard to }\end{array}$ & Indicator & Expressed as & Explanation/Interpretation \\
\hline & $\begin{array}{l}1 \text { - Population supplied by groundwater / } \\
\text { Total population of the WRMU }\end{array}$ & $\%$ & $\begin{array}{l}\text { Importance of groundwater for suppling the } \\
\text { population of each WRMU. }\end{array}$ \\
\hline Dependence & $\begin{array}{l}2 \text { - Total abstraction of groundwater (all uses) / } \\
\text { Total subsurface and surface water abstraction }\end{array}$ & $\%$ & $\begin{array}{l}\text { Amount of exploited groundwater for all } \\
\text { uses (household, agriculture, industries) } \\
\text { with regard to the total amount of exploited } \\
\text { surface- and subsurface resources. }\end{array}$ \\
\hline \multirow{2}{*}{ Availability } & $\begin{array}{l}3 \text { - Exploitable reserves of groundwater / } \\
\text { Total population of the WRMU }\end{array}$ & L/inhab/day & $\begin{array}{l}\text { The exploitable reserves of groundwater } \\
\text { correspond to the renewable groundwater } \\
\text { resources, that consist of the difference } \\
\text { between the recharge and the discharge that } \\
\text { maintains the baseflow in the rivers. }\end{array}$ \\
\hline & $\begin{array}{l}4 \text { - Total abstraction of groundwater / } \\
\text { Exploitable reserves of groundwater }\end{array}$ & $\%$ & $\begin{array}{l}\text { Denote areas where over-exploitation and } \\
\text { its social-economic impacts were already } \\
\text { identified. The exploitable reserves of } \\
\text { groundwater may vary according to the } \\
\text { current social-economic, political and } \\
\text { ecological conditions of each region. }\end{array}$ \\
\hline \multirow{3}{*}{ Quality } & $\begin{array}{l}5 \text { - Total area of high vulnerability to } \\
\text { contamination / Total area of the WRMU }\end{array}$ & $\%$ & $\begin{array}{l}\text { Area of the WRMU that is susceptible to } \\
\text { any kind of contamination. It was based } \\
\text { in the map of vulnerability of the State of } \\
\text { São Paulo (Hirata et al. 1997) that was } \\
\text { elaborated according to the GOD method } \\
\text { (Foster and Hirata 1988). }\end{array}$ \\
\hline & $\begin{array}{l}6 \text { - Total area with natural contamination of } \\
\text { groundwater / Total area of the WRMU }\end{array}$ & $\%$ & $\begin{array}{l}\text { The total area of the WRMU with natural } \\
\text { contamination corresponds to the sum of } \\
\text { the municipality areas where contamination } \\
\text { was verified. It helps visualyzing, in time } \\
\text { and space, problems related to natural } \\
\text { quality. }\end{array}$ \\
\hline & $\begin{array}{l}7 \text { - Total number of proved cases of anthropic } \\
\text { contamination / Total area of the WRMU }\end{array}$ & $\begin{array}{l}\text { Number of } \\
\text { cases } / \mathrm{km}^{2}\end{array}$ & $\begin{array}{l}\text { Number of cases of soil and groundwater } \\
\text { contamination caused by human activities } \\
\text { (such as fuel stations, industries, waste } \\
\text { disposal sites, trade, and accidents) by } \\
\mathrm{km}^{2} \text { of the WRMU. }\end{array}$ \\
\hline
\end{tabular}

sources, and consequently, clearly demonstrates the availability with regard to the currently practiced abstractions. An estimate of I4, for the State of São Paulo, when considering the calculated values for each WRMU, corresponds to $12 \%$. It points out the potentiality of supplying water for various purposes, especially due to the fact that, excepting punctual cases, this resource presents good quality (see Indicators 6 and 7). Excepting WRMUs Turvo Grande (52\%), Pardo (44\%), Upper Tietê (41\%), Mogi-Guaçu and Tietê/Jacaré (28\%) basins where the use is quite intense, the rest of them show values less than $20 \%$ (category low), being the majority less than $10 \%$ (Table V). For the Piracicaba/Capivari/Jundiai Basin, with acknowledged intense use of groundwater, the value of I4 is only $4 \%$, however I3, which takes into account the population of the basin, denotes that its situation is problematic (Table V). Investigations of potentiality, carried out by private consultants in order to attend the need of licensing expressive discharges, have demonstrated that, for small areas, the renewable groundwater resources are very limited in Piracicaba/Capivari/Jundiai Basin. This situation demonstrates that the major problem of this basin is the great density of abstractions, due to the concentration of human occupation, on aquifers (Tubarão and Precambrian systems) whose discharges are limited by their hydraulic conductivity and storativity.

In the Upper Tietê Basin, a recent study (Hirata et al. 2002) has concluded that the piezometric levels of the aquifers have been lowered and, consequently, there have been reserve losses, due to uncontrolled exploitation of groundwater. Nevertheless, I4 also reveals that, 


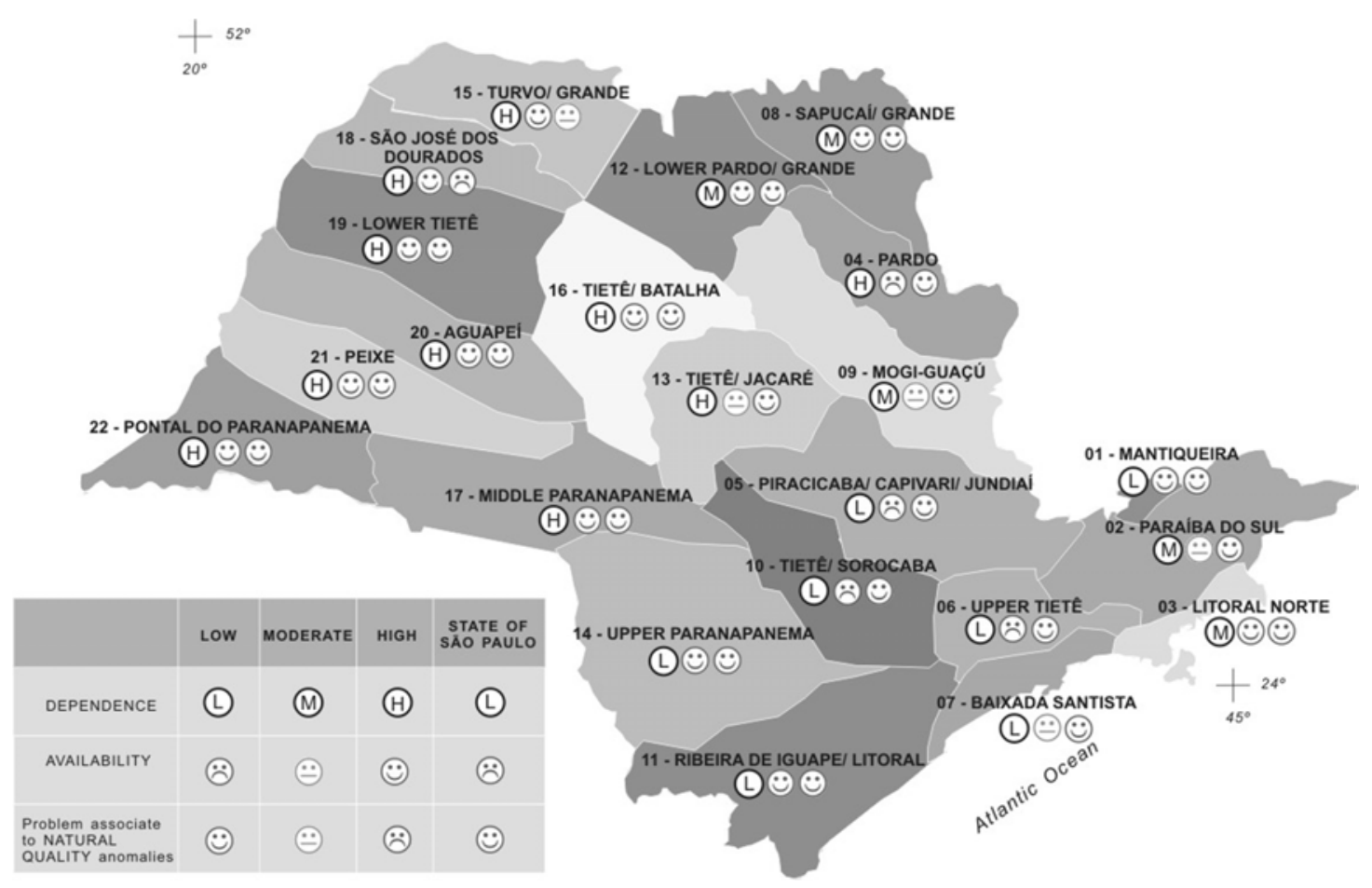

Fig. 3 - Example of material for public awareness using groundwater indicators.

outside of the urbanized areas, this resource could be $100 \%$ more exploited than it currently is.

\section{INDICATORS OF GROUNDWATER QUALITY}

Indicator 5 (I5) (Table IV) considers the relative extension, in each WRMU, of areas of different vulnerabilities, which is an intrinsic characteristic of an aquifer, and is defined as the susceptibility of the saturated zone of the aquifer becoming contaminated, according to current potability parameters, by an anthropic activity (Foster and Hirata 1988). I5 does not consider the interaction of the vulnerability with the potential contaminant loads for the reason that there is not an up to date evaluation of their distribution.

GOD method (Foster and Hirata 1988) was applied for the mapping of the vulnerability of the aquifer systems of the State of São Paulo in 1:500.000 (Hirata et al. 1997). I5 points out that the most vulnerable WRMUs correspond to Pardo, Tietê/Jacaré, Lower Tietê, Aguapeí, Pontal do Paranapanema, Paraíba do Sul, Peixe, São José dos Dourados, Sapucai/Grande and Upper Paranapanema. One important area of high vulnerability, correspond to recharge zones of the Guarani Aquifer Sys- tem, especially in the WRMUs of Pardo, Mogi-Guaçu, and Upper Paranapanema (Table IV). Therefore, detailed studies of existent contamination and careful evaluations, when considering the installation of future activities, should be carried out in these regions. The vulnerability of the WRMUs totally located in crystalline terrains is not defined.

Indicator 6 (I6) (Table IV) denotes the total area where the natural quality of groundwater is not in accordance with drinking water standards. In the State of São Paulo, the most common elements, related to the natural solubilization of minerals of the host rock by the percolation of groundwater, are fluoride and total chromium, as toxic components, and iron and manganese, as aesthetic parameters. In the present study, only the first two are considered.

According to I6 the natural quality of the groundwater of the State is, in general, excellent, however contamination of fluoride are found in Paranapanema, Tietê/Batalha, and Middle Paranapanema basins; of chromium, in São José dos Dourados, Turvo/Grande, and Lower Pardo/Grande; and of both components in Lower Tietê. The greater values of I6 were found in São José 


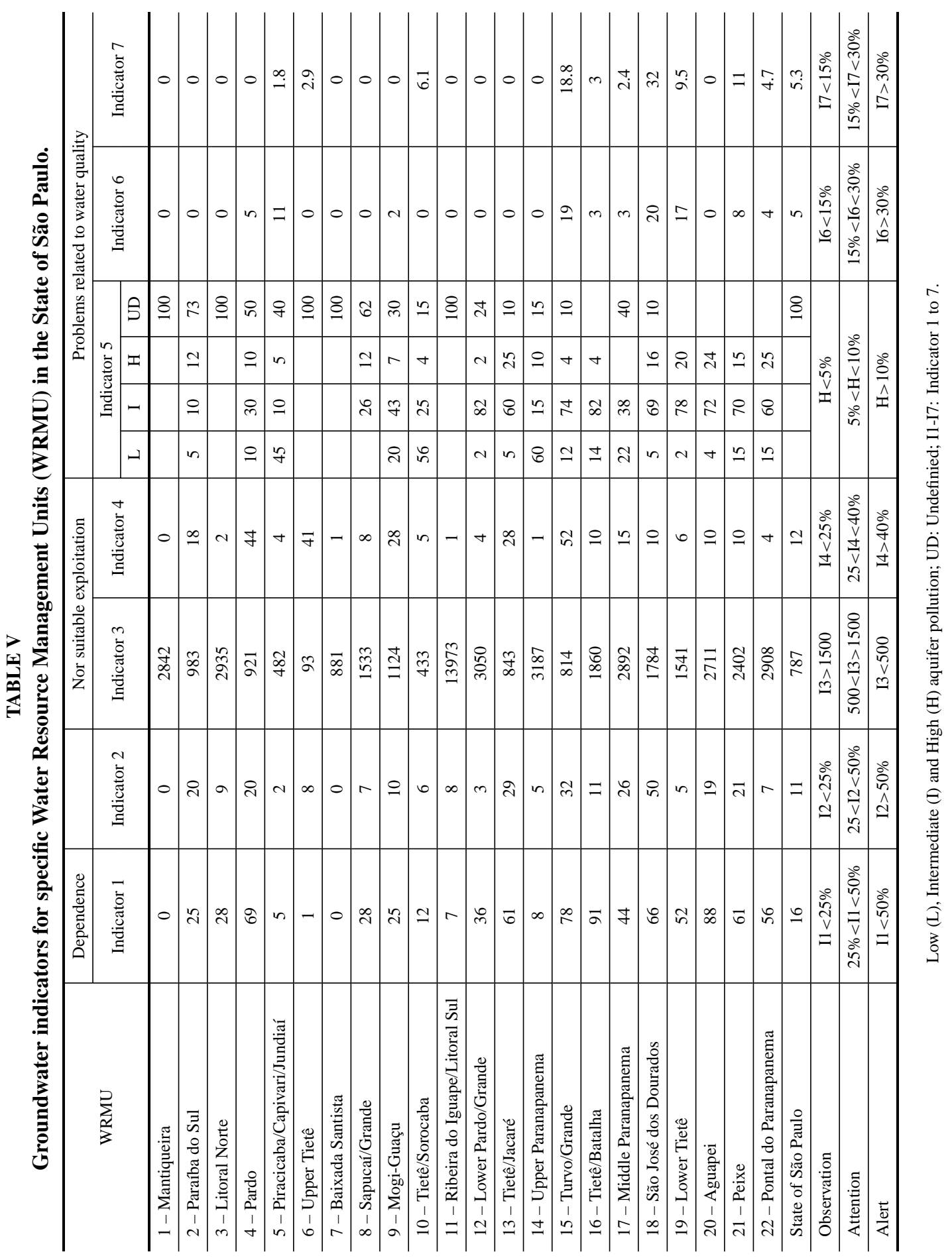


dos Dourados (20\%), Turvo/Grande (19\%), Lower Tietê $(17 \%)$ and Piracicaba/Capivari/Jundiai (11\%), which were classified as category high (Table V). Once the actual extension of the areas where the contamination occurs is not known, the calculation of this Indicator took into account the total area of the municipality where the contamination was detected.

Indicator 7 (I7) relates the number of contaminated groundwater sites to the total area of WRMU. The main problem related to this indicator is the lack of information. A government program for detecting groundwater contamination sites in the State of São Paulo is new, and up to now, few of them were studied in detail. The inventory of contaminated areas, elaborated by CETESB, responsible for the State environmental control, reports, up to November of 2004, the existence of 1366 confirmed cases of contamination (among tens of thousands of potentially contaminant sources), of which 931 were caused by fuel stations, 237 by industries, 61 by solid waste disposal, 92 by trade associated activities (including storing and handling of hazardous products), and 15 by accidents of unknown origin (http:// www.cetesb.sp.gov.br, access on 05/05/05). The majority of the contaminated sites is located in urban areas of the Upper Tietê Watershed (725 cases), followed by Piracicaba/Capivari/Jundiai Basin (182 cases).

\section{CONCLUSIONS}

The indicators herein proposed, together with the available information for each WRMU, are suitable to evaluate the current situation of the groundwater in the State of São Paulo. Three different combinations of these indicators provide a general picture of three aspects, namely, current (1) dependence, (2) availability and (3) quality of groundwater.

The dependence of groundwater for the State of São Paulo is remarkable and can be evaluated by indicators 1 and 2. With regard to the public supply (Indicator 1), one observes that 9 WRMUs show high (more than $50 \%$ of the population is supplied by groundwater), 6 , intermediate (49 to $25 \%$ ), and 7, low (less than 24\%) dependence on groundwater. The largest demand is geographically located in the North, Central and Western portions of the State. On the other hand, considering the supply of groundwater for any purpose (Indicator 2), the dependence on groundwater is expressively smaller, and only one WRMU (Middle Paranapanema) is in the category high, and three and 18 WRMUs in categories intermediate and low, respectively.

The groundwater availability is assessed by indicators 3 and 4 . Indicator 4 points out that the resource still presents a great potential for further abstractions in most of the WRMUs. However the Upper Tietê, followed by Turvo/Grande, and Pardo basins show evidence of overexploitation and need special attention. In the specific case of Upper Tietê Basin, followed by Piracicaba/Capivari/Jundiai, and Turvo/Grande, the volume of water divided by the population (Indicator 3 ) clearly denotes the low availability.

The quality of groundwater is demonstrated by indicators 5, 6 and 7. In WRMUs 2, 4, 8, 13, 14 and 18 to 22 more than $10 \%$ of their territory is of high vulnerability, which denotes that they need to be more carefully considered, when large potential contaminant loads are present or planned to be installed. Some of these basins contain part of the recharge area of the Guarani Aquifer System, the most productive aquifer in Brazil. Indicator 6 points out its general excellent natural quality, although it also denotes that some WRMUs (São José dos Dourados, Turvo/Grande, and Piracicaba/Capivari Jundiai) need special consideration with regard to chromium and fluoride concentrations. The majority of the cases of contamination caused by human activities is concentrated in urban areas.

In spite of the groundwater resources of good quality in the State of São Paulo being fairly abundant, there are some specific areas where the WRMUs are currently facing problems such as overexploitation (strong drawdown in particular urban areas), low availability (related to population concentration) and contamination (natural and anthropic). In this way, the indicators, that can be easily understandable by policy-makers, represent an important tool for identifying areas that should be either prioritized for detailed studies or worked in a preventive way.

\section{ACKNOWLEDGMENTS}

The authors are most grateful to Ms Thelma Samara (Instituto de Geociências, USP) for the preparation of the figures of this article. 


\section{RESUMO}

Indicadores, para recursos hídricos subterrâneos, têm sido utilizados principalmente para a avaliação da situação atual e tendência de degradação, com relação tanto à quantidade (subou super-exploração) como à qualidade (contaminações natural e antrópica). Neste sentido, este trabalho apresenta a aplicação de indicadores com o objetivo de obter um quadro geral da situação dos recursos hídricos nas 22 Unidades de Gerenciamento de Recursos Hídricos (UGRHI) do Estado de São Paulo. Foram aplicados 7 indicadores (I1 a I7) com o objetivo de fornecer uma visão geral com relação à dependência (I1 e I2), disponibilidade (I3 e I4), e qualidade (I5, I6 e I7) da água subterrânea. No que se refere ao abastecimento público (indicador 1), 9 UGRHIs apresentam alta (>50\% da população é suprida por água subterrânea), 6, intermediária (49 a 25\%) e 7, baixa ( $<24 \%$ ) dependência do recurso hídrico subterrâneo. Os indicadores 3 e 4 mostram que o recurso ainda apresenta grande potencial para explotações adicionais na maioria das UGRHIs, no entanto há evidências de superexploração nas bacias do Alto Tietê, Turvo/Grande e Pardo e baixa disponibilidade nas bacias do Alto Tietê, Piracicaba/Capivari/Jundiaí, e Turvo/Grande. O indicador 5 (vulnerabilidade natural dos aquíferos) aponta que as UGRHIs 2, 4, 8, 13, 14 e 18 a 22 (parte da área aflorante do Sistema Aqüífero Guarani) precisam ser mais cuidadosamente consideradas, principalmente quando grandes cargas contaminantes potenciais estiverem presentes. $\mathrm{O}$ indicador 6 revela que a qualidade natural das águas subterrâneas é de modo geral excelente, ainda que 3 UGRHIs necessitem de cuidados especiais especiais devido à sua contaminação por cromo e flúor. O indicador 7 mostra uma forte relação entre a ocorrência da contaminação das águas subterrâneas e densidade/tipo de ocupação territorial.

Palavras-chave: água subterrânea, São Paulo, abastecimento público, gestão, indicadores.

\section{REFERENCES}

CETESB. 2004. Relatório de Qualidade das Águas Subterrâneas 2001-2003. São Paulo, SP, Brasil, 211 p.

Foster S AND HiRata R. 1988. Groundwater pollution risk evaluation: a survey manual using available data. Pan American Center for Sanitary Engineering and Environmental Sciences PAHO/WHO. Lima, Peru, 98 p.
Hirata R AND FERreira L. 2001. Os aqüíferos da bacia hidrográfica do Alto Tietê: disponibilidade hídrica e vulnerabilidade à poluíção. Rev Brasil Geoc 31: 43-50

Hirata R, Bastos C and Rocha G. 1997. Mapeamento da vulnerabilidade e risco de poluição das águas subterrâneas no Estado de São Paulo. IG/CETESB/DAEE, Secretaria do Meio Ambiente do Estado de São Paulo (Série Documentos). 2 vol.

Hirata R, Ferreira L, Ferreira L and Pede M. 2002. La explotación de las aguas subterráneas en la cuenca hidrográfica del Alto Tietê: crónica de una crisis anunciada. Madrid. In: Boletín GeOlóGICO Minero 113: 273-282.

Perroni J, Silva R, Hirata R And DozZy L. 1985. Ocorrência de fluoreto nos aqüíferos da Bacia do Paraná no Estado de São Paulo. $5^{\circ}$ Simpósio Regional de Geologia. São Paulo, SP, Brasil, SBG 503: 514.

SÃo PAUlo. 2004a. Plano de Bacia da Unidade de Gerenciamento de Recursos Hídricos Turvo/Grande. Instituto de Pesquisas Tecnológicas. Relatório Técnico. São Paulo, SP, Brasil, 92 p.

SÃo PAUlo. 2004b. Plano Estadual de Recursos Hídricos: Síntese dos Planos de Bacia. Relatório 1. JMS-Engecorps. Departamento de Águas e Energia Elétrica. São Paulo, SP, Brasil, 378 p.

SEADE. 2004. Anuário estatístico do Estado de São Paulo. Fundação SEADE. São Paulo (http://www.seade.gov.br/, access on 15/10/04).

SRACEK O AND HiRAtA R. 2002. Geochemical and stable isotopic evolution of the Guarani Aquifer System in the State of São Paulo, Brazil. Hydrogeol J 10: 643-655.

UNESCO, IAEA, IAH, UNECE. 2004. Development of groundwater indicators for second edition of the World Water Development Report. Groundwater indicators Working Group (Jaroslav Vrba, Jan Girman, Naim Haie, Ricardo Hirata, Annukka Lipponen, Tushaar Shah and Bill Wallin). Third Version (UNESCO Technical Report), Paris, France, 18 p.

Vrba J, Hirata R, Girman J, Haie N, Lipponen A, SHAH T AND WALlin B. 2005. Groundwater resources sustainability indicators. In: VII IAHS SCIENTIFIC AsSEMBLY, Foz do Iguaçu, PR, Brazil. 